\title{
REKONSILIASI KOSMOLOGIS Antara Teorema Penciptaan dan Teori Evolusi
}

\author{
Leo Agung Srie Gunawan*
}

\begin{abstract}
The problem of the universe having a great mystery encloses the big question about its origin. To answer the origin of universe, generally, there are two approaches, namely faith and science. The main question has to be replied: "What do the differences and the similarity of them?" The approach of faith bases on the inquiry of "who causes the existence of the universe". This approach states that the origin of universe was created by God and hence, it was formed by God from a nothingness (creatio ex nihilo). This is known as the theorem of creation. Furthermore, the scientific approach is grounded on the research of "how the universe was formed in the beginning". This oncoming being explained by the Big Bang Theory, which is continued by the Big Crunch Theory, asserts that the origin of universe came from the prime matter which exploded incredibly in a such a way that the formation process of the universe took place (the singularity). This is well-known as the theory of evolution (the cosmological evolution). In conclusion, the scientific approach explaining the process of creation and the faith one answering the actor of it are complementary.
\end{abstract}

Kata-kata Kunci: teorema penciptaan - teori evolusi, creation ex nihilo singularitas, Big Bang - Big Crunch.

Alam semesta adalah fakta yang tak terhindarkan dalam hidup kita. Kita hidup di alam semesta baik secara mikrokosmos (jagad cilik) dan makrokosmos (jagad gedhe). ${ }^{1}$ Kita merangkai sejarah hidup kita dengan segala problematikanya di alam semesta. Keberadaan alam semesta ini menarik perhatian bagi para pemikir Yunani sejak awal. Para filsuf Yunani menggunakan arkhê sebagai prinsip untuk menjelaskan asal-mula alam semesta. Thales (624-546 SM) berpendapat bahwa air sebagai

\footnotetext{
* Leo Agung Srie Gunawan, lisensiat dalam bidang ilmu Filsafat; lulusan Universitas Gregoriana, Roma; dosen Filsafat pada Fakultas Filsafat Unika St. Thomas, Sumatera Utara.

${ }^{1}$ Falsafah Jawa menggunakan kedua istilah ini untuk menjelaskan realitas alam yang kita hayati. Jagad cilik adalah hidup setiap orang yang merupakan dunia kecil dan sekaligus berpartisipasi dalam alam semesta. Sementara jagad gedhe merupakan kenyataan alam semesta dengan segala isinya.
} 
prinsip asal-mula alam semesta. Alasannya adalah bahwa air memenuhi sebagian besar alam sekitar. Selanjutnya, kehidupan mengandaikan air; tanpa air tidak ada kehidupan. ${ }^{2}$ Anaximenes (586-526 SM) berpendapat bahwa prinsip segala sesuatu ada pada udara. Segala yang berkaitan dengan kehidupan membutuhkan udara. Tanpa udara, semua manusia akan mati. ${ }^{3}$ Phytagoras (570-495 SM) mengemukakan bahwa prinsip segala sesuatu berasal dari angka-angka; Angka dapat membentuk garis, ruang dan volume sebagai prinsip pertama dalam alam semesta. ${ }^{4}$

Secara khusus, Anaximandros (610-540 SM) adalah filsuf yang memikirkan tentang asal-usul alam semesta dengan prinsip terakhir sebagai "to apeiron": "yang tak terbatas". Aperion bersifat ilahi, abadi, tak berubah dan meliputi alam semesta. Karena suatu perceraian (ekkrisis), maka dilepaskan dari apeiron itu unsur-unsur berlawanan ( $t a$ enatia): yang panas dan yang dingin, yang kering dan yang basah. Kejadian dunia berlangsung ketika yang panas membalut yang dingin, sehingga bersama-sama merupakan bola raksasa. Karena kepanasan, maka dalam yang dingin itu air mulai melepaskan diri dari tanah dan mulai berkembang juga udara atau kabut. Karena tekanan yang disebabkan oleh udara itu, bola meletus menjadi sejumlah lingkaran. Tiap-tiap lingkaran terdiri dari api yang dilingkupi dengan udara. Karena setiap lingkaran mempunyai lubang, api yang terkandung di dalamnya dapat dilihat. Itulah matahari, bulan, dan bintang-bintang. ${ }^{5}$

Asal-usul alam semesta ini mempunyai dua sumber penjelasan. Pertama, jika alam semesta ada, asal-usulnya berasal dari Sang Pencipta. Alam semesta diciptakan oleh Sang Pencipta. Pada bagian ini, alam semesta tidak dapat tidak berada karena diciptakan oleh Allah. Kedua, jika alam semesta ini ada, keberadaannya merupakan hasil proses alam. Proses ini berlangsung dalam waktu yang lama. Berdasarkan teleskop Hubble, alam semesta lahir berkisar 13-15 milyar tahun yang lalu,

${ }^{2}$ Lih. K. Bertens, Sejarab Filsafat Yunani, hlm. 35-36.

${ }^{3}$ Lih. K. Bertens, Sejarah Filsafat Yunani, hlm. 39-40.

${ }^{4}$ Lih. K. Bertens, Sejarah Filsafat Yunani, hlm. 45-48.

${ }^{5}$ Lih. K. Bertens, Sejarah Filsafat Yunani, hlm. 36-37. 
sementara bumi baru terbentuk sekitar 3-4 juta tahun yang lalu. ${ }^{6}$ Dalam evolusi alam semesta, Sang Pencipta tidak dibicarakan sebagai penyebab dari alam semesta. Yang dibicarakan dalam evolusi adalah proses berlangsungnya alam semesta sebagai proses alam. Dua pendekatan ini menjelaskan tentang asal-usul alam semesta yang berbeda. Pendekatan penciptaan diidentikkan dengan keyakinan iman dan pendekatan evolusi disamakan dengan pengetahuan ilmiah. Seringkali kedua pendekatan ini saling bertentangan.

Berdasarkan pendekatan penciptaan sebagai "teorema penciptaan" dan pendekatan evolusi sebagai "teori evolusi", asal-usul alam semesta dihadapkan pada pertanyaan-pertanyaan sebagai berikut: Manakah pendekatan yang benar: pendekatan penciptaan atau pendekatan evolusi?; Apa perbedaan dari kedua pendekatan ini?; Apakah ada persamaan dari kedua pendekatan ini?; Bagaimana mendamaikan pendekatan penciptaan dan pendekatan evolusi sehingga kedua pendekatan dapat saling melengkapi untuk menjelaskan asal-usul alam semesta?

\section{Dua Istilah}

"Teori" dan "teorema" adalah dua istilah yang tampaknya mempunyai kesamaan makna. Padahal, kedua istilah ini berbeda maknanya dan tidak bisa dipertukarkan begitu saja; Misalnya, Teori Relativitas tidak bisa dikatakan sebagai Teorema Relativitas. Demikian juga, Teorema Phytagoras tidak dapat dikatakan sebagai Teori Phytagoras. ${ }^{7}$ Ada beberapa unsur yang membedakan antara istilah "teori" dan "teorema".

\footnotetext{
${ }^{6}$ Tentang usia alam semesta yang menjadi ukuran lahirnya alam semesta, para astrolog tidak sepakat. Stephen Hawking menyatakan bahwa alam semesta lahir berkisar 13,7 milyar tahun yang lalu; Allan Sandage menyatakannya kira-kira 15 milyar tahun, sedangkan, Wendy Freedman hanya berkisar 9-12 milyar tahun yang lalu; Bdk. Franz Dähler, Teori Evolusi: Asal dan Tujuan Manusia, hlm. 32.

7 Teorema berasal dari bahasa Yunani, theorem: spekulasi. Proposisi ini digunakan dalam fisika dan matematika. Sebuah teorema merupakan pernyataan yang telah dibuktikan dengan pengadaian dari asumsi yang eksplisit (Bdk. https://www.quora.com (Dikutip: Selasa, 15 Januari 2019).
} 
Kita perlu menjelaskan perbedaan antara "teori" dan "teorema" sebagai titik tolak pembicaraan kita $^{8}$. Teori itu menyangkut penjelasan yang dapat diverifikasi. Yang dapat diverifikasi berarti kita dapat menunjukkan pembuktiannya. Karena itu, sebuah teori adalah hasil pemikiran untuk menjelaskan mengapa sesuatu ide menjadi benar (teori gravitasi) atau sesuatu hal memiliki hukum tertentu (hukum newton). Dalam konsep teori, tekanan terdapat pada pemikiran saintis yang berciri empiris. Jika disebut empiris, maksudnya adalah informasi-informasi yang diperlukan untuk sebuah teori diperoleh melalui observasi dari pengalaman. Dalam sebuah teori, skema dari pemikiran dinyatakan sebagai sebuah penjelasan dari sejumlah fakta atau fenomena yang diobservasi. Akibatnya, sebuah hipotesis diteguhkan oleh pengamatan dari pengalaman. Sebagai rumusan, teori dinyatakan sebagai hukum, prinsip, atau penyebab umum dari suatu hal yang diobservasi. Kita dapat mengatakan bahwa sebuah teori adalah model induktif yang digunakan untuk menjelaskan fakta-fakta (Theory - Inductive model used to explain facts).

Sementara itu, teorema adalah penjelasan yang dapat didemonstrasikan. Yang dapat didemonstrasikan berarti bahwa kita dapat melakukan lagi untuk menunjukkan kepada orang lain tentang pembuktiannya. Sebuah teorema adalah hasil pemikiran yang dapat dibuktikan menjadi benar dari sejumlah aksioma. ${ }^{9}$ Istilah ini khususnya digunakan dalam matematika yang di dalamnya aksioma-aksioma yang merupakan logika matematika dan sistem-sistem dalam pertanyaan. ${ }^{10}$

\footnotetext{
${ }^{8}$ Bdk. https://english.stackexchange.com (Dikutip: Selasa, 15 Januari 2019).

9 Aksioma adalah pernyataan yang dapat diterima sebagai kebenaran tanpa harus membuktikannya. Kata ini berasal dari $\alpha \xi ı \varepsilon \iota \nu$ (axioein), yang berarti dianggap berharga, yang kemudian berasal dari $\alpha \xi$ เoৎ (axios), yang berarti berharga. Di antara banyak filsuf Yunani, suatu aksioma adalah suatu pernyataan yang bisa dilihat kebenarannya tanpa perlu adanya bukti. Kata aksioma juga dimengerti dalam matematika. Kata aksioma dalam matematika juga disebut postulat. Akan tetapi, aksioma dalam matematika bukan berarti proposisi yang terbukti dengan sendirinya, melainkan, suatu titik awal dari sistem logika. Misalnya, 1+1=2. Nama lain dari aksioma adalah postulat. Suatu aksioma adalah basis dari sistem logika formal yang bersama-sama dengan aturan inferensi mendefinisikan logika (Bdk. https://id.wikipedia.org/wiki/Aksioma; Dikutip: 18 Januari 2019)

${ }^{10}$ Contoh-contoh aksioma dalam matematika: 1) Dengan melalui 2 titik sembarang hanya bisa dibuat suatu garis lurus. 2) Apabila sebuah garis serta sebuah bidang itu memiliki dua
} 
Konsep teorema secara fundamental berdasar pada model deduktif. Sementara, model deduktif berasal dari logika dan akal budi, bukan fakta-fakta. Dalam sebuah teorema, pernyataan universal tidaklah jelas dari dirinya sendiri tetapi dapat didemonstrasikan melalui argumenargumen. Karena itu, sebuah teorema merupakan kesimpulan dari model deduktif yang berdasarkan fakta-fakta (Theorem - Conclusion by deduction from facts).

Secara praktis, sebuah teorema dapat dikatakan: "Kita dapat membuat pernyataan; Kita tahu bagaimana cara membuktikannya; selanjutnya kita membuktikan dengan bantuan parameter yang lain; sebuah teorema dapat dibuktikan dengan berbagai cara. Sementera, sebuah teori dapat dikatakan: "Kita membuat tesis yang didasarkan pada argumen atau prinsip tertentu; kita dapat menempatkan lebih jauh setiap alasan yang mungkin untuk membuat pernyataan/teori yang benar. ${ }^{11}$

Lebih jauh, sebuah teori menyimpulkan sejumlah hipotesis yang didukung oleh uji coba yang berulang-ulang dan kepastian cocok untuk seluruh pengetahuan yang telah diformulasikan. Teori menjadi valid sejauh tidak ada bukti-bukti yang menyangsikannya. Sementara, teorema adalah pernyataan matematis konkret yang dibuktikan dari sejumlah aksioma atau hasil-hasil yang dibuktikan sebelumnya. Pada umumnya kata "teori mempunyai makna di luar bidang matematika; Misalnya, "teori konspirasi", "teori evolusi”, "teori gravitasi”. Sementara, sebuah teorema adalah pernyataan yang dapat dibuktikan secara matematis. Teorema hanya menjadi benar dalam arti bahwa teorema adalah konsekuensi dari aksioma yang logis. Pernyataan-pernyataan kita gunakan sebagai titik tolak untuk proses deduktif dan untuk mendefinisikan sebuah wilayah matematis yang kita pelajari. Misalnya, Teorema Phytagoras adalah pernyataan benar yang dapat dibuktikan

titik persekutuan, maka garis itu seluruhnya terletak pada suatu bidang. 3) Dengan melalui tiga buah titik sembarang hanya bisa dibuat sebuah bidang. 3) Dengan sebuah titik yang ada di luar sebuah garis tertentu, hanya bisa dibuat sebuah garis yang sejajar dengan garis tertentu (lih. https://pendidikan.co.id/aksioma-dan-teorema-pengertian-syarat-dan-contoh; Dikutip: 18 Januari 2019).

${ }^{11}$ Bdk. https://www.quora.com (Dikutip: Selasa, 15 Januari 2019). 
tentang sudut segitiga siku-siku yang merupakan bagian dari wilayah dari geometri dari Euclides. ${ }^{12}$

\section{Dua Pendekatan}

Berbicara mengenai eksistensi alam semesta, kita dapat menggunakan dua pendekatan. Pertama, pendekatan dengan Teorema Penciptaan yang berpangkal dari Allah sebagai Pencipta. Kedua, pendekatan dengan Teori Evolusi alam semesta yang berpangkal dari alam sebagai ciptaan. Pada bagian selanjutnya, kita akan membahasnya satu-persatu.

\section{Teorema Penciptaan}

Jika dalil Phytagoras adalah sebuah teorema yang didasarkan pada aksiomanya; Ini artinya teorema Phytagoras mendasarkan bahwa aksioma adalah pernyataan yang dapat diterima sebagai kebenaran tanpa harus membuktikannya. Kisah penciptaan merupakan sebuah teorema penciptaan, bukan teori penciptaan.

Pernyataan bahwa kisah penciptaan adalah teorema bukan teori mempunyai beberapa alasan. Pertama, kisah penciptaan tidak dapat dijadikan objek observasi langsung (teori), tetapi kisah penciptaan merupakan aksioma tentang adanya dunia. Aksioma adalah bahwa segala sesuatu yang di dunia ada yang menciptakan; Dunia dan segalanya isinya adalah ciptaan, maka dunia dan segala isinya ada yang menciptakan (teorema). Kedua, kisah penciptaan tidak dapat diverifikasi. Jalan verifikasi mengandaikan adanya bukti. Jika kisah penciptaan merupakan kisah antara ciptaan dan Pencipta, hal ini berarti ciptaan harus dapat dibuktikan dan Pencipta juga harus dapat dibuktikan. Tentang ciptaan sebagai akibat tindakan Pencipta, kita dapat memberikan buktinya; buktinya adalah bahwa dunia ini ada sebagai ciptaan. Tetapi, tentang Pencipta sebagai pelaku yang menciptakan, kita tidak dapat membuktikan secara langsung sebagai objek pengalaman yang dapat diobservasi sebagaimana halnya objek inderawi. Dengan demikian, Sang Pencipta

${ }^{12}$ Bdk. Bdk. https://www.quora.com (Dikutip: Selasa, 15 Januari 2019. 
dunia tidak dapat diverivikasi, tidak dapat dibuktikan sebagai objek inderawi; Allah tidak dapat dilihat, didengar, dicium, dicecap, dan diraba. Adanya Sang Pencipta hanya dapat didemonstrasikan. Usaha mendemonstrasikan adanya Allah sebagai Sang Pencipta dapat dilakukan melalui lima jalan dari St. Thomas Aquinas untuk mengetahui bahwa Allah benar-benar ada (quinque viae ad deum). Jalan pertama adalah gerak, bahwa segala sesuatu bergerak, setiap gerakan pasti ada yang menggerakkan, namun pasti ada sesuatu yang menggerakkan sesuatu yang lain, namun tidak digerakkan oleh sesuatu yang lain, Dialah Allah; Jalan kedua adalah sebab akibat, bahwa setiap akibat mempunyai sebabnya, namun ada penyebab yang tidak diakibatkan, Dialah sebab pertama, Allah; Jalan ketiga adalah keniscayaan, bahwa di dunia ini ada hal-hal yang bisa ada dan ada yang bisa tidak ada (contohnya adalah benda-benda yang dahulu ada ternyata ada yang musnah, namun ada juga yang dulu tidak ada ternyata sekarang ada), namun ada yang selalu ada (niscaya) Dialah Allah; Jalan keempat adalah pembuktian berdasarkan derajat atau gradus melalui perbandingan, bahwa dari sifat-sifat yang ada di dunia (yang baik-baik) ternyata ada yang paling baik yang tidak ada tandingannya (sifat Allah yang serba maha) Dialah Allah; Jalan kelima adalah penyelenggaraan, bahwa segala ciptaan berakal budi mempunyai tujuan yang terarah menuju yang terbaik, semua itu pastilah ada yang mengaturnya, Dialah Allah. ${ }^{13}$ Ketiga, kisah penciptaan disebut sebagai teorema karena metode pendekatan yang mungkin adalah deduktif. Metode deduktif mulai dengan pengandaian bahwa dunia ini diciptakan oleh Sang Pencipta. Dari pengandaian ini, kita bisa menjelaskan berdasarkan bukti dari ciptaan. Kisah penciptaan tidak dapat disebut sebagai teori penciptaan sebab ilmu pengetahuan tidak dapat melakukan observasi sampai ke titik awal (13,7 milyar tahun yang lalu). ${ }^{14} \mathrm{Jika}$ hal itu terjadi, aspek pengandaian tak terhindarkan untuk menyatakan berlangsungnya kisah penciptaan.

\footnotetext{
${ }^{13}$ Bdk. Battista Mondin, Epistemologia Cosmologia (Vol.2), hlm. 240-244.

${ }^{14}$ Ini adalah kesimpulan dari Stephen Hawking tentang umur alam semesta (Lih. Stephen Hawking - Leonard Mlodinov, The Grand Design (Terj. Zia Anshor, Rancang Agung), hlm. 148).
} 
Secara khusus, ungkapan "teorema penciptaan” dinyatakan oleh G. Bontadini untuk memecahkan kontradiksi inheren dalam perubahan; Yang dimaksudkan perubahan oleh Bontadini adalah perubahan dari eksistensi ciptaan. Kontradiksi ini hadir sebagai identitas dalam perubahan yang selalu bergerak antara "kutub positif" dan "kutub negatif". Selanjutnya, kontradiksi ini dijelaskan melalui "teorema penciptaan" yang di dalamnya Pencipta yang hakikatnya tak berubah (L'Immobile) menciptakan ciptaan yang hakikatnya berubah (il deveniente). Dalam hal ini, Sang Pencipta menetapkan baik "kutub positif" dan "kutub negatif"; keduanya saling berinteraksi dalam $\operatorname{ciptaan}^{15}$.

Kisah penciptaan sebagai "teorema penciptaan" diajarkan dalam Katekismus Gereja Katolik. Pertama, Allah mencipta dari ketiadaan. Allah dalam mencipta tidak membutuhkan sesuatu yang ada lebih dahulu dan tidak membutuhkan bantuan apa pun. Ciptaan itu pun tidak mengalir secara paksa dari substansi ilahi. Allah mencipta dengan bebas dari ketiadaan (creatio ex nihilo). ${ }^{16}$ Allah sendiri menciptakan alam semesta secara bebas, langsung, dan tanpa bantuan apa pun; Karena itu, tidak ada makhluk yang mempunyai kekuasaan tak terbatas yang perlu untuk "mencipta" dalam arti kata yang sebenarnya; artinya, menghasilkan sesuatu yang sama sekali belum ada, dan memberi kepadanya keberadaan, memanggilnya "dari ketiadaan ke dalam keberadaan" (ex nihilo nihil existit). ${ }^{17}$ Kedua, alam semesta menerima keberadaanya dari Sang Pencipta. Dunia mulai, ketika ia diciptakan oleh Allah dari ketiadaan. Segala makhluk yang ada, seluruh alam, seluruh sejarah umat manusia, berakar dalam kejadian pokok ini; oleh "kejadian" ini seluruh

\footnotetext{
15 Kisah Penciptaan lebih pada "teorema" daripada "teori" mempunyai arti yang meyakinkan dalam pemikiran filosofis. Dengan istilah "teorema", filsafat mampu menjelaskan pendasaran dari alam semesta (Lih. Battista Mondin, Epistemologia Cosmologia (Vol.2), hlm. 246-247).

16 "Seandainya Allah menciptakan dunia ini dari bahan yang sudah ada sebelumnya, lalu apakah sebenarnya yang luar biasa? Kalau memberikan bahan kepada seorang tukang, Ia akan membuat dari bahan itu segala sesuatu yang Ia kehendaki. Akan tetapi kekuasaan Allah menyatakan diri, karena Ia bertolak dari ketiadaan untuk membuat segala sesuatu yang Ia kehendaki”" (Teofilus dari Antiokia, Autol. 2, 4); Lih. Katekismus Gereja Katolik, No. 296.

${ }^{17}$ Bdk. Katekismus Gereja Katolik, No. 317 dan 318.
} 
dunia dibentuk dan waktu mulai bergulir. ${ }^{18}$ Allah sebagai Pencipta disebut sebagai "Yang Pertama" dan "Yang Terakhir". Sebutan ini mau mengatakan bahwa segala sesuatu di alam semesta ini berada di dalam Allah. Allah menjadi penyebab keberadaan alam semesta dan seluruh alam semesta tertuju kepada Allah. Terutama kehidupan manusia sebagai makhluk ciptaan tertinggi yang masa depannya mendapatkan finalitasnya di dalam Allah. ${ }^{19}$ Ketiga, Allah menciptakan alam semesta demi kemuliaan-Nya; "Dunia diciptakan demi kemuliaan Allah" ${ }^{20}$ ". Penjelasannya adalah Allah menciptakan segala sesuatu "bukan untuk menambah kemuliaan-Nya, melainkan untuk mewartakan dan menyampaikan kemuliaan-Nya". Allah tidak mempunyai alasan lain untuk mencipta selain cinta-Nya dan kebaikan-Nya. ${ }^{21}$

Teorema penciptaan menurut Kitab Kejadian ${ }^{22}$ hanya berlangsung enam hari Kisah ini dituangkan dalam Kejadian 1:1-31 ${ }^{23}$ dan seluruh kisah penciptaan yang berlangsung enam hari ditutup dengan: "Maka, Allah melihat segala yang dijadikan-Nya itu, sungguh amat baik. Jadilah petang dan jadilah pagi, itulah hari keenam" (Kej 1:31). Inilah urutan kisah penciptaan dalam kitab Kejadian yang diakui oleh para kreasionis. Hari pertama, ketika bumi masih gelap, dingin, dan tak berbentuk, Allah

\footnotetext{
${ }^{18}$ Bdk. Katekismus Gereja Katolik, No. 338.

${ }^{19}$ Bdk. Katekismus Gereja Katolik, No. 198.

${ }^{20}$ Konsili Vatikan I; DS 3025.

${ }^{21}$ Bdk. Katekismus Gereja Katolik, No. 293; "Satu-satunya Allah yang benar ini telah mencipta dalam kebaikan-Nya dan "kekuatan-Nya yang mahakuasa - bukan untuk menambah kebahagiaan-Nya, juga bukan untuk mendapatkan [kesempurnaan], melainkan untuk mewahyukan kesempurnaan-Nya melalui segala sesuatu yang Ia berikan kepada makhluk ciptaan - karena keputusan yang sepenuhnya bebas, menciptakan sejak awal waktu dari ketiadaan sekaligus kedua ciptaan, yang rohani dan yang jasmani” (DS 3002)

${ }^{22}$ Inilah pernyataan yang mendukung bahwa kisah penciptaan dilukiskan dalam Kitab Suci: "The proposed creation model derives its framework from The biblical description of God's creative activity. The process of building this model is ongoing. Refinements continue taking place as new information and insight becomes available" (Fazale Rana \& Hugh Ross, Life of Origin, hlm. 25).

${ }^{23}$ Menurut John A. Moore, urutan kisah penciptaan dalam Kitab Kejadian adalah sebagai berikut: penciptaan surga dan bumi (1:1), penciptaan terang (1:3), penciptaan cakrawala (1:6), penciptaan bumi dipisahkan dari air (1:9), penciptaan hasil-hasil di bumi (1:11), penciptaan matahari, bulan, dan bintang-bintang (1:14), penciptaan ikan dan unggas $(1: 20)$, penciptaan binatang buas dan ternak (1:26), penciptaan manusia sebagai gambar dan rupa Allah (1:26), dan perjanjian tentang tanggung-jawab manusia (1:29); (From Genesis to Genetics: The Case of Evolution and Creationism, hlm. 31).
} 
(Elohim) menciptakan terang dan malam. Hari kedua, Allah menciptakan cakrawala untuk memisahkan air di atas dan air di bawah. Hari ketiga, Allah memisahkan daratan dan air dan menciptakan tumbuh-tumbuhan. Hari keempat, Allah menciptakan matahari, bulan, dan bintang-bintang. Hari kelima, Allah menciptakan hewan-hewan yang berkeriapan di dalam air dan burung-burung di udara. Hari keenam, Allah menciptakan bintang-bintang lain dan manusia. Akhirnya, hari ketujuh, Allah istirahat dari segala pekerjaannya. ${ }^{24}$ Hal ini ditegaskan: "Ketika Allah pada hari ketujuh telah menyelesaikan pekerjaan yang dibuat-Nya itu, berhentilah Ia pada hari ketujuh dari segala pekerjaan yang telah dibuat-Nya itu” (Kej $2: 2)$.

Teorema Penciptaan yang berdasarkan pada Kitab Kejadian dapat disimpulkan tiga kebenaran tentang penciptaan. Tentang pelaku penciptaan, Allah adalah Pelaku dari seluruh karya penciptaan. St. Atanasius menegaskan: "Kita percaya hanya satu Allah yang menciptakan, Allah mahakuasa, pencipta segala sesuatu yang kelihatan dan tak kelihatan, yang berasal dari dirinya sendiri berada". ${ }^{25}$ Dengan menyatakan bahwa Allah adalah Pelaku penciptaan, seluruh alam semesta ini ada bukan karena "peristiwa kebetulan" dan juga bukan karena "kekuatannya sendiri" (alam semesta ada karena berasal dari dirinya sendiri). Tentang bahan penciptaan, Allah melakukan karya penciptaan dari ketiadaan. Biasanya ciptaan dibuat berdasarkan bahan yang sudah ada; gedung pencakar langit diciptakan dari bahan bangunan; teori relativitas lahir dari pemikiran ilmuwan sebelumnya; manusia lahir dari pertemuan sel telur dan sel sperma. Sampai-sampai dikatakan bahwa tidak ada yang baru di muka bumi ini. Pernyataan ini mau mengatakan bahwa segala ciptaan di dunia berasal dari sesuatu yang sudah ada sebelumnya. Tak pernah ada ciptaan yang berasal dari ketiadaan, selain Allah yang melakukannya. Allah tidak membutuhkan bahan apa pun dalam karya penciptaan-Nya. Hal ini menyatakan bahwa Allah Mahakuasa dan Mahapencipta. Tentang waktu penciptaan, waktu yang

${ }^{24}$ Lih. John A. Moore, From Genesis to Genetics: The Case of Evolution and Creationism, hlm. 36. 25 "Nous croyons en un seul Dieu inengendré, Père toutpuissant, créateur de toutes les choses visibles et invisibles, qui a par lui-même l'exister ..." (Claude Tresmontant, La métaphysique du Christianisme et la naissance de la philosophie chrétienne, hlm. 107). 
dibutuhkan dalam karya penciptaan adalah enam hari. Dengan menyatakan waktu penciptaan, kita dapat mengatakan bahwa segala yang diciptakan masuk ke dalam wilayah waktu. Penciptaan dan waktu adalah dua hal yang tak bisa dipisahkan. Segala yang tercipta bereksistensi dalam waktu dan ruang.

\section{Teori Evolusi}

Pada umumnya, kita mengartikan evolusi sebagai perubahan dalam sifat-sifat yang diturunkan dari populasi makhluk hidup yang berlangsung dari generasi ke generasi. ${ }^{26}$ Pengertian evolusi ini adalah pengertian evolusi yang sempit (the narrow definition). Hal ini ditegaskan oleh Eugene Scott, yang menyatakan bahwa seringkali evolusi dipahami secara sempit. Terhadap pertanyaan, "Apa itu evolusi?" Kebanyakan orang akan menjawab, "Manusia berasal dari monyet" atau "molekul-molekul mengarah kepada pembentukan manusia". Evolusi merupakan asal-usul kehidupan lebih daripada soal manusia; evolusi menyangkut materi alam semesta, lebih daripada soal segala sesuatu yang hidup. Selanjutnya, Scott mengusulkan pengertian evolusi yang luas (the broad definition). Pengertian evolusi adalah "sebuah perubahan yang menyeluruh yang berlangsung dalam perjalanan waktu"; Evolusi mengacu kepada fakta bahwa alam semesta mempunyai sebuah sejarah. Dengan menoleh ke belakang kepada masa lampau, kita akan menemukan bintang, galaksi, dan planet yang berbeda serta bentukbentuk kehidupan di muka bumi ini yang berbeda pula. Ada evolusi kosmologis, evolusi geologis, dan evolusi biologis. Inilah penjelasan lebih lanjut dari Scott:

Evolusi butuh untuk didefinisikan lebih luas bersama dengan masing-masing disiplin ilmu karena baik fenomena yang dipelajari dan proses-mekanisme dari evolusi kosmologis, evolusi geologis,

\footnotetext{
${ }^{26}$ Sifat-sifat ini merupakan penampakan dari gen-gen yang berasal dari "orang tua" kepada keturunannya selama reproduksi. Sifat-sifat yang berbeda lahir sebagai populasi yang baru sebagai hasil dari mutase, rekombinasi yang diturunkan, dan sumber-sumber dari variasi yang diturunkan. Evolusi berlangsung dalam proses yang panjang sebagai hasil dari seleksi alam (natural selection), termasuk juga seleksi seksual (sexual selection) dan penyimpangan yang diwariskan (genetic drift); Bdk. https://en.wikipedia.org/wiki/Evolution; Dikutip, Kamis, 24 Januari 2019.
} 
dan evolusi biologis merupakan hal yang berbeda. Evolusi kosmologis berkaitan dengan asal-usul dari elemen-elemen alam semesta, bintang-bintang, galaksi-galaksi, dan planet-planet. Evolusi geologis berkaitan dengan evolusi dalam planet itu sendiri tentang asal-usul dan perubahan menyeluruh yang berlangsung dalam waktu. Mekanisme dari evolusi kosmologis dan geologis melibatkan prinsip dan hukum fisik dan kimia: termodinamika, panas, dingin, perluasan, konstraksi, erupsi, sedimentasi, dan seterusnya. Sementara, evolusi biologis adalah kesimpulan berdasarkan fakta bahwa segala sesuatu yang hidup berasal dari nenek moyang yang sama dan diturunkan dengan modifikasi dari nenek moyangnya ini. ${ }^{27}$

Evolusi kosmologis dijelaskan oleh Teori Big Bang. Sebagai evolusi kosmologis, alam semesta bermula dengan materi padat dengan tenaga yang mahadahsyat. Materi itu meledak dengan sangat dahsyat sehingga gumpalan-gumpalan gas dan debu menjauh dengan kecepatan yang sangat tinggi. Ledakan ini terlempar ke segala penjuru. Ledakan purba yang mahadahsyat ini disebut dengan Ledakan Besar (Big Bang). Inilah permulaan alam semesta dan dengan ini dimulai juga waktu. Sebelum ada Ledakan Besar belum ada waktu, dan keadaan ini disebut sebagai singularitas ${ }^{28}$; Singularitas merupakan momentum ketika suhu, kerapatan, dan kelengkungan alam semesta semuanya bernilai tak terhingga. Dengan kata lain, singularitas adalah kenyataan yang tidak bisa diukur dan tidak diatur oleh hukum alam. ${ }^{29}$ Singularitas merupakan penyebab terjadinya dua wilayah. Pertama, singularitas merupakan awalmula yang berkembang dalam alam semesta (the present expansion of the universe). Dengan ini, singularitas pada umumnya dianggap sebagai awal-usul alam semesta. Kedua, singularitas merupakan ledakan partikelpartikel dari konsentrasi masa yang menjadi cikal-bakal bintang-bintang dalam alam raya (high-mass concentration such as burnt-out stars). ${ }^{30}$

\footnotetext{
${ }^{27}$ Eugene C. Scott, Evolution and Creation, hlm. 23.

${ }^{28}$ Bdk. Franz Dähler, Teori Evolusi: Asal dan Tujuan Manusia, hlm. 31.

29 Bdk. Stephen Hawking - Leonard Mlodinov, The Grand Design (Terj. Zia Anshor, Rancang Agung), hlm. 138.

${ }^{30}$ Lih. Stephen Hawking, The Big Bang and Black Holes, hlm. 117
} 
Dalam Teori Big Bang, kita mendapatkan pengetahuan tentang awal mula terjadinya alam semesta yang dikisahkan dalam Kitab Kejadian.

Stephen Hawking menjelaskan bahwa satu detik setelah peristiwa Big Bang, temperatur berkisar 10 milyar derajat Celcius. Pada saat itu alam semesta memuat foton, elektron, neutron, proton, dan neutron. ${ }^{31}$ Kebanyakan elektron dan antielektron (positron) saling membinasakan diri dan menciptakan foton (bagian elementer terkecil dari sinar). Kirakira seratus detik kemudian, temperatur jatuh ke 1 milyar derajat saja. Proton dan neutron menyatukan diri menjadi inti atom hidrogen berat (deuterium), lalu terbina inti atom helium dan inti dari beberapa unsur kimiawi lebih berat seperti lithium. Beberapa jam saja setelah Big Bang, terbentuklah zat helium dan unsur-unsur kimiawi lain. Dengan turunnya temperatur ke beberapa ribuan derajat Celcius, elektron-elektron dan intiinti atom menyatukan diri - karena daya tarik-menarik masing-masing menjadi atom-atom. Dengan demikian, kita sampai pada kekuatan inti dari alam semesta. ${ }^{32}$

Menurut Karen C. Fox, ada tiga fakta yang mendukung Teori Big Bang. Pertama, alam semesta ini terus berkembang dengan memperluas wilayahnya. Kedua, alam semesta ini berisi gas helium dan atom-atom yang lain yang merupakan jejak masa lampau. Ketiga, sisa-sisa dari radiasi dalam alam semesta berasal dari Ledakan Besar pada awal mula alam semesta. ${ }^{33}$ Selanjutnya, Barry Parker melukiskan kelanjutan dari peristiwa Ledakan Besar dalam alam semesta:

Meskipun, seluruh cahaya yang berkedip dan galaksi-galaksi bertumbuh dalam wilayah gas dalam jumlah yang sangat besar, pada akhirnya kumpulan gas itu menyatu. Pada tahap ini alam semesta terdiri dari sebuah gas yang sangat tipis dalam sebuah latar

\footnotetext{
${ }^{31}$ Foton adalah partikel dasar atau kuantum radiasi elektromagnet; elektron adalah satuan muatan listrik negatif; neutron adalah partikel inti atom yang tidak bermuatan listrik dan massanya sedikit lebih besar daripada massa proton; proton adalah partikel bermuatan listrik positif yang terdapat di dalam inti atom; dan neutron adalah partikel inti atom yang tidak bermuatan listrik dan massanya sedikit lebih besar daripada massa proton (KBBI, https://kbbi.web.id; Dikutip: 31 Januari 2019).

${ }^{32}$ Lih. Franz Dähler, Teori Evolusi: Asal dan Tujuan Manusia, hlm. 32-33.

${ }^{33}$ Lih. Karen C. Fox, The Big Bang Theory, hlm. 69.
} 
belakang hitam seperti tinta, tetapi tampak aneh, fluktuasi kecil diturunkan oleh sebuah gelombang yang mengejutkan yang terjadi dalam hitungan detik dari sebuah peristiwa Big Bang berada di dalamnya. Sebagai alam semesta terus mengembang akibat panas gas dan apa yang sekali tidak tampak dari radiasi gelombang kecil mulai memancarkan sinarnya. Awalnya berwarna merah, perlahanlahan berubah menjadi kuning muda, selanjutnya putih kebiruan. Akhirnya, pada suhu kira-kira 3000 Keseluruh ruang berkobar seperti permukaan pada bintang berwarna putih yang cemerlang. Sampai sekarang, kita dapat melihat melalui kabut tipis, tetapi seluruhnya kita lihat sekarang kumpulan kabut putih yang tercampur. Di dalam kabut ini, meskipun hanya berbentuk nucleus ada deuterium, lithium dan sebagian besar helium. ${ }^{34}$

Sementara, Eugene C. Scott menjelaskan bahwa fakta Ledakan Besar ini dijumpai pada bintang-bintang yang berasal dari efek-efek yang mempunyai gaya gravitasi pada gas yang berputar-putar sebagai sisa dari peristiwa Big Bang. Berawal dari gas helium, elemen-elemen yang lebih berat dibentuk dalam energi yang menjadi sumber dari bintang-bintang terkini melalui penggabungan atom. Elemen-elemen ini dibentuk sekitar 10-12 juta tahun. Selanjutnya, Bumi baru terbentuk sekitar 4-5 juta tahun yang silam. Planet Bumi terbentuk dari kumpulan materi yang mengitari Matahari. Pada waktu awal, wajah Bumi berbeda tidak seperti yang kita lihat sekarang. Pada waktu itu, Bumi adalah tempat yang tidak ramah untuk ditempati karena dipenuh dengan radiasi, dibombardir oleh meteor dan komet, dipenuhi bahan kimia dari gunung berapi, dan dipenuhi oleh retakan-retakan masif dari kerak planet. Sebuah hipotesis menyatakan bahwa atmosper Bumi berasal dari gas yang melampaui batas di Bumi dan air yang ada di permukaan Bumi berasal dari komet-komet yang menabrak Bumi. Bumi dibombardir oleh komet dan meteor selama 3,8 juta tahun lalu. Dalam situasi seperti ini, hidup tidak mungkin

${ }^{34}$ Barry Parker, Creation: The Story of the Origin and Evolution of the Universe, hlm. 97-98. 
berlangsung. Baru setelah pembombardiran dari komet dan meteor berhenti, benih-benih kehidupan mulai tampak. ${ }^{35}$

Evolusi alam semesta bertitik tolak dari peristiwa Big Bang yang terus berproses. Berdasarkan Big Bang, alam semesta terus berkembang (the expansion of universe). Alam semesta terus melakukan ekspansinya dalam jagad raya ini. Stephen Hawking menegaskan: "Penemuan bahwa alam semesta yang mengembang adalah salah satu revolusi intelektual terbesar pada abad kedua puluh". ${ }^{36}$ Berkaitan dengan ekspansi alam semesta, Alexander Friedmann (1922) adalah orang pertama yang menyatakan bahwa alam semesta terus berekspansi yang berasal dari sebuah ledakan sebagai titik tolaknya. Setelah itu, Edwin Hubble (1929) menemukan hubungan antara perubahan sinar merah dalam spektrum dari bintang, galaksi, atau gugusan galaksi dengan jarak dari objek-objek tersebut. $^{37}$

Pertama, Alexander Friedmann (1888-1925) adalah penggagas tentang ekspansi alam semesta (the universe is expanding). Dalam teori tentang ekspansi alam semesta, ia menggunakan dua asumsi yang sangat sederhana terhadap alam semesta: alam semesta terlihat identik ke mana pun kita memandang, dan hal ini berlaku juga jika kita mengamati alam semesta dari semua tempat lain. Berdasarkan asumsinya, Friedmann menunjukkan bahwa kita seharusnya tidak menganggap bahwa alam semesta itu statis. ${ }^{38}$ Pada suatu waktu di masa lampau, sekitar 10-12 milyar tahun, jarak antara galaksi-galaksi mesti nol. Dalam perkembangannya, galaksi-galaksi tak pernah berada di tempat yang

\footnotetext{
35 Miller menyatakan: “Ada yang tampak menjadi kimia organik universal, salah satu yang merupakan perwujudan ruang antar bintang-bintang berlangsung dalam atmosfer dari planet-planet mayor dari tata surya, dan harus juga terjadi dalam atmosfer yang berkurang pada Bumi pada mulanya" (Lih. Eugene C. Scott, Evolution and Creation, hlm. 23-24)

36 Menurut Stephen Hawking, Isaac Newton dengan Teori Gravitasinya masih meyakini bahwa alam semesta itu statis. Demikian juga, Albert Einstein dengan merumuskan Teori Relativitasnya masih sangat yakin bahwa alam semesta harus statis untuk dapat memodifikasi teorinya (Lih. Stephen Hawking, A Brief History of Time (Terj. Zia Anshor, Sejarah Singkat Waktu, hlm. 57-58).

${ }^{37}$ Lih. I.N. Tolstikhin - J.D. Kramers, The Evolution of Matter. From the Big Bang to the Present Day, hlm. 44.

${ }^{38}$ Lih. Stephen Hawking, A Brief History of Time (Terj. Zia Anshor, Sejarah Singkat Waktu, hlm. 59 .
} 
sama, dan hanya perlu pernah berdekatan satu sama lain. ${ }^{39}$ Menurut Friedmann, semua galaksi bergerak menjauh dari galaksi lain. Keadaan ini mirip balon dengan sejumlah titik di kulitnya, yang sedikit demi sedikit ditiup hingga mengembang; selagi balon mengembang, jarak antara sembarang dua titik membesar, tetapi tidak ada titik yang bisa disebut sebagai pusat pengembangan. Dalam perkembangan alam semesta, kecepatan pergerakan menjauh antara dua galaksi sebanding dengan jarak antara kedua galaksi. ${ }^{40}$

Perkembangan alam semesta diwarnai dengan kelahiran bintangbintang baru. Di alam semesta terdapat ketegangan besar antara daya gravitasi sebagai daya tarik dan daya sentrifugal sebagai daya ekspansi. Gravitasi memperlambat perluasan alam semesta dan memadatkan energi. Inilah saat kelahiran galaksi yang berputar. Jika suatu bintang memadatkan diri sedemikian dahsyat hingga meledak, terbentuklah bintang baru yang disebut supernova. Menurut pengamatan para ahli astrofisika, hampir setiap detik muncul satu supernova baru dalam alam semesta, sedangkan erupsi sinar gamma disaksikan satu kali sehari. ${ }^{41}$

Dua grup saintis pada pertengahan tahun 1990-an, yang satu dikenal sebagai Proyek Kosmologi Supernova dan Tim Supernova High-Z melakukan penelitian supernova-supernova yang jaraknya 4 sampai 7 juta tahun. Dalam jarak tersebut, kumpulan supernova ini akan tampak jelas dalam perubahan warna merah yang ditunjukkan. Ini berarti kumpulan supernova bergerak sangat cepat dari kita sesuai dengan hukum Hubble bahwa alam semesta sedang melakukan perluasan (the universe is expanding). Objek yang lebih jauh akan pudar lebih cepat daripada objek yang lebih dekat.

\footnotetext{
${ }^{39}$ Bdk. Stephen Hawking, A Brief History of Time (Terj. Zia Anshor, Sejarah Singkat Waktu, hlm. 68-71.

${ }^{40}$ Lih. Stephen Hawking, A Brief History of Time (Terj. Zia Anshor, Sejarah Singkat Waktu, hlm. 64).

${ }^{41}$ Supernova baru ditemukan pada tahun 1987, maka bintang itu disebut sebagai Supernova 1987 A. Demikian juga, pada tahun 1998, satelit Italia-Belanda BeppoSAX menyaksikan erupsi sinar gamma, yang dihubungkan dengan Supernova SN 1998. Energinya sepuluh kali lipat melebih Supernova 1987 A. Letusannya begitu hebat hingga materi lepas lari keluar dengan kecepatan yang hampir setara dengan kecepatan cahaya (Lih. Franz Dähler, Teori Evolusi: Asal dan Tujuan Manusia, hlm. 33).
} 
Sebuah supernova yang jaraknya 7 juta tahun perjalanan cahaya sama dengan usianya yang sudah berlangsung. Kecepatan supernova menjadi kecepatan perjalanannya. Perubahan warna merah yang menandakan kecepatan supernova merupakan kecepatan yang sedang menggembara ketika alam semesta telah mencapai usianya sekarang ini... Data dari supernova ini menunjukkan bahwa perluasan alam semesta menjadi semakin cepat. Alam semesta sedang berada dalam akselerasi perluasan. ${ }^{42}$

Kedua, Edwin Hubble (1889-1953) meneguhkan teori tentang ekspansi alam semesta (the universe is expanding); Pernyataan Friedmann tentang perluasan alam semesta diafirmasi oleh Hubble. Teori Friedmann dibuktikan melalui pengamatan Hubble. Dalam pengamatan terhadap benda angkasa, Hubble didukung dengan teleskop yang berkekuatan 100-inch $(2.5 \mathrm{~m})$. Melalui teleskopnya, ia memeriksa hubungan antara jarak galaksi dan perubahan warna merah pada galaksi (the redshifts of galaxy). Dengan menggabungkan ukuran-ukurannya pada jarak galaksi dengan ukuran-ukuran perubahan warna merah, ia menemukan hubungan linier antara jarak galaksi-galaksi dan perubahan warna merahnya. Penemuan ini selanjutnya dikenal dengan hukum Hubble. ${ }^{43}$ Dalam kaitannya dengan perubahan warna merah, betapa cepat sebuah objek di langit bergerak menjauhi Bumi. Berdasarkan informasi ini, Hubble menggambarkan alam semesta yang di dalamnya objek-objek menjauh sedang bergerak cepat. Karena itu, Hubble menyimpulkan bahwa alam semesta sedang memperluas wilayahnya. Para astronom

\footnotetext{
42 Karen C. Fox, The Big Bang Theory, hlm. 140-141.

43 "The Hubble parameter and The age of The Universe. The Hubble diagram of recession velocities versus distances obtained by observations on supernovae SNe Ia. The slope of The regression line gives $\mathrm{H} 0=72 \pm 2 \mathrm{~km} \mathrm{~s}-1 \mathrm{Mpc}-1$. The inset presents less distant objects, with an inferred $\mathrm{H} 0=75 \pm 8 \mathrm{~km} \mathrm{~s}-1 \mathrm{Mpc}-1$. Thus The velocity-distance dependence seen in Fig. 4.4 appears to be valid for both remote and neighbouring objects, from which The light signals travel $\sim 1$ Gyr and $\sim 1$ Myr respectively. Recently a fully independent determination of The Hubble parameter, based on measurements of The cosmic microwave background radiation, has yielded $71 \pm 4 \mathrm{~km} \mathrm{~s}-1 \mathrm{Mpc}-1$, in excellent agreement with The redshift-derived value. This agreement confirms The model of The expanding Universe, and from These observations The time when expansion started, i.e. The age of The Universe, can be derived. The best-fit value is $13.7 \pm 0.2$ Gyr" (Tolstikhin, I.N. - Kramers, J.D. The Evolution of Matter: From The Big Bang to The Present Day. The Evolution of Matter, hlm. 50).
} 
menerima kesimpulan Hubble tanpa ragu; mereka mulai mengasosiasikan perubahan warna merah yang terdapat pada objek-objek yang sangat jauh di langit. Perubahan warna merah pada galaksi/bintang menjadi hubungan intrinsik tentang bagaimana kita menentukan kecepatan objek yang diamati dan tentang berapa usia dan berapa jaraknya. ${ }^{44}$

Jika alam semesta terus berekspansi di jagad semesta ini, apakah perkembangan alam semesta sebagai kisah evolusi kosmos berlangsung tanpa batas? Dengan kata lain, apakah alam semesta akan terus berkembang tanpa akhir? Jika ini benar, kita sudah berada dalam keabadian; keabadian berarti tanpa batas, tanpa ruang dan waktu lagi! Padahal semasih disebut alam semesta, ia mau tak mau berada dalam struktur ruang dan waktu (the universe is constituted by space and time). Ruang dan waktu sendiri adalah substansi material. Sebagai substansi material, ruang dan waktu tidak dapat bersifat tak terbatas; ruang dan waktu itu terbatas dan tidak abadi. Karena itu, kita harus mengatakan bahwa ekspansi alam semesta itu terbatas. Dalam hal ini, Stephen Hawking mengemukakan Teori Big Crunch: "Dilukiskan dengan baik oleh model ruangan mahakecil yang di dalamnya kita mampu menghitung kemungkinan tentang hubungan antara sebuah alam semesta yang ditakdirkan untuk berakhir dan dalam sebuah penyusutan hebat alam semesta (a big crunch) dan sebuah gerakan ekspansi tanpa akhir alam semesta (an eternal de sitter expansion)". ${ }^{45}$ Teori Big Crunch menyatakan bahwa alam semesta akan menyusut sampai pada titik nol karena alam semesta akan kehabisan energinya. Selanjutnya, Hawking menjelaskan bahwa "panah waktu dari hukum termodinamika" yang berdasarkan pada prediksi dari relativitas umum, menyatakan bahwa ada "ruang dan waktu singular" yang berada baik di masa lampau dalam peristiwa Ledakan Besar (Big Bang) maupun di masa depan dalam Penyusutan Besar (Big Crunch). Dalam peristiwa Penyusutan Besar (the Big Crunch), alam semesta akan hancur, atau masuk dalam lubang hitam, atau bagian-bagian tertentu alam semesta akan hancur. Jika pada masa lampau, "ruang dan waktu singular" berada pada "titik nol materi", dari sanalah, permulaan tatanan mulai secara perlahan-lahan. Karena itu,

${ }^{44}$ Karen C. Fox, The Big Bang Theory, hlm. 128-129.

${ }^{45}$ Lih. Fang Li Zhi - Remo Ruffini (Ed.), Hawking on The Big Bang and Black Holes, hlm. 28. 
Penyusutan Besar akan menempatkan alam semesta pada "ruang dan waktu singular" yang akan menempatkan pada "titik nol materi" juga. Itu berarti akan ada kehancuran alam semesta. ${ }^{46}$

Akhirnya, berkaitan dengan evolusi alam semesta, Stephen Hawking mengajukan pertanyaan-pertanyaan fundamental: "Mengapa ada sesuatu, bukan ketiadaan? Mengapa ada hukum alam tertentu, bukan yang lain?" Menanyakan siapa yang menciptakan alam semesta itu masuk akal, tapi jika jawabannya adalah Tuhan, maka pertanyaannya sekadar bergeser menjadi siapa yang menciptakan Tuhan. Dalam pandangan demikian, diakui bahwa ada sesuatu yang tak perlu pencipta, dan sesuatu disebut Tuhan. Tapi kami nyatakan bahwa pertanyaanpertanyaan itu semuanya bisa dijawab dalam ranah sains saja, tanpa perlu membawa-bawa sosok ilahi. ${ }^{47}$ Berdasarkan pernyataan Hawking, seolah-olah proses evolusi alam semesta tidak perlu campur tangan Allah. Seolah-olah evolusi alam semesta hanya semata-mata peristiwa natural, bukan peristiwa supranatural. Apakah penjelasan evolusi alam semesta dengan Teori Big Bang tidak memerlukan keterlibatan Allah? Apakah dengan teori evolusi alam semesta, peran Allah sebagai pencipta telah dikuburkan. Demikian juga, apakah setelah pasca Penyusutan Besar alam semesta (a Big Crunch), sejarah dunia berakhir tanpa bekas dan sejarah manusia berakhir tanpa makna. Terhadap hal ini, bagaimana kita harus menanggapinya?

\section{Rekonsilasi Penciptaan dan Evolusi}

Dua pendekatan tentang eksistensi alam semesta mau tidak mau merupakan dua pendekatan yang berbeda. Dalam keadaan ini, kita mau membuat rekonsiliasi antara kedua pendekatan ini. Baik dalam perbedaan maupun persamaan keduanya, kita mau membuat rekonsiliasi kosmologis di dalamnya. Ini adalah rekonsiliasi yang menyangkut pendamaian antara dua pendekatan tentang eksistensi alam semesta.

\footnotetext{
${ }^{46}$ Bdk. Fang Li Zhi - Remo Ruffini (Ed.), Hawking on The Big Bang and Black Holes, hlm. 32.

${ }^{47}$ Lih. Stephen Hawking - Leonard Mlodinov, The Grand Design (Terj. Zia Anshor, Rancang Agung), hlm. 182.
} 


\section{Perbedaan Keduanya}

Pertama-tama, kita harus mengatakan bahwa ada perbedaan teorema penciptaan dan teori evolusi kosmos. Dari istilah yang digunakan, sudah tersirat perbedaannya yang mendasar. Teorema penciptaan berdasarkan pengandaian tentang adanya dunia yang diciptakan. Pengandaian itu berupa aksioma sebagai pernyataan yang dapat diterima sebagai kebenaran tanpa harus membuktikannya. Lebih jauh, teorema penciptaan dalam Kitab Kejadian adalah refleksi iman tentang penciptaan. Iman yang merefleksikan siapa di balik ciptaanciptaan di alam semesta ini. Kitab Kejadian lebih pada buku iman. Sementara teori evolusi kosmos menjelaskan penyelidikan tentang adanya alam semesta. Sebagai teori, evolusi kosmologis mendasarkan teorinya pada penelitian ilmiah yang berdasarkan pada data-data empiris. $^{48}$

Perbedaan antara teori penciptaan dan teori evolusi kosmos menyangkut pendekatan. Kita dapat mengatakan teorema penciptaan menggunakan pendekatan dari atas (top-down); Sementara, teori evolusi kosmos memakai pendekatan dari bawah (bottom-up). Dalam teorema penciptaan, pendekatan dari atas terdapat pada gagasan Allah menciptakan alam semesta; Pengada tak terbatas mengadakan kenyataan yang terbatas (top-down). Sementara, teori evolusi kosmos melakukan penyelidikan pada objek-objek di alam semesta; alam semesta adalah kenyataan sekarang ini. Berdasarkan penyelidikannya, teori evolusi menyelidiki sejarah alam semesta (asal-usul, kejadian, dan keberlangsungannya). Teori evolusi mendasarkan pada objeknya masa kini untuk mencari tahu sejarahnya. Dalam teori evolusi, ada "gerakan dari bawah" sebagai masa sekarang "menuju ke atas" sebagai masa lampau (bottom-up). Pendekatan ini tampak dalam Teori Big Bang yang menyelidiki tentang "kelahiran alam semesta"; Alam semesta lahir pada

\footnotetext{
48 Istilah "evolusi kosmos" dapat diartikan sebagai evolusi tentang alam semesta (The evolution of universe); evolusi mengacu kepada "objek penyelidikannya". Sementara istilah "evolusi kosmologis" digunakan untuk membedakan ada evolusi biologis dan evolusi geologis (Eugene Scott). Istilah evolusi kosmologis mau menekankan "karakter dari bidang ilmunya" (The cosmological evolution). Keduanya mengacu pada hal yang sama, yaitu evolusi yang menjelaskan tentang sejarah alam semesta.
} 
saat terjadi Ledakan Besar yang berasal dari "singuralitas-materi". Selanjutnya pendekatan bottom up juga dapat dipahami sebagai pendekatan pada objek yang diamati masa sekarang bergerak ke masa depan. Ketika Friedmann dan Hubble berbicara tentang ekspansi alam semesta, mereka menyatakan secara tidak langsung bahwa alam semesta bergerak menuju masa depannya. Dari waktu ke waktu, dari masa sekarang ke masa depan alam semesta sedang melakukan perluasan wilayahnya (the universe is expanding). ${ }^{49}$

Selain perbedaan pendekatan, ada perbedaan konsep waktu antara Terorema Penciptaan dan Teori Evolusi. Untuk penciptaan alam semesta, Kitab kejadian hanya butuh 6 hari dan Teori Bing Bang memerlukan kurang-lebih 13,7 milyar tahun. Kitab Kejadian mengkisahkan penciptaan alam semesta hanya berlangsung 6 hari. Hari ketujuh, Allah beristirahat yang dihayati sebagai Hari Sabat. Berkaitan dengan kisah penciptaan ini; Di satu pihak, orang akan mengatakan bahwa sah-sah bagi Allah menciptakan alam semesta beserta isinya berlangsung 6 hari. Alasannya jelas bahwa Allah itu Mahakuasa yang mampu melakukan apa saja sesuai dengan kekuasaannya. Di lain pihak, orang akan berasionalisasi tentang "waktu Pencipta" dan "waktu ciptaan”. Kutipan yang sering dipakai: “... yang satu ini tidak boleh kamu lupakan, yaitu, bahwa di hadapan Tuhan satu hari sama seperti seribu tahun dan seribu tahun sama seperti satu hari" (2Pet 3:8). Lalu, orang akan berhitung jika 1 hari sama dengan 1000 tahun maka 6 hari penciptaan membutuhkan 6000 tahun.

\footnotetext{
${ }^{49}$ Berkaitan dengan perluasan alam semesta, kita berhadapan dengan pertanyaan yang pelik: "Apakah alam semesta mempunyai batas?" Jika kita menjawab bahwa alam semesta mempunyai batas, hal ini mengandaikan bahwa alam semesta berada dalam sebuah wadah mahabesar. Dalam hal ini, pengandaiannya adalah bahwa wadah harus ada di dalam wadah, dan seterusnya. Padahal ini tidak mungkin. Jika kita menjawab bahwa alam semesta tidak berbatas, kita sudah masuk dalam dunia immaterial yang sudah tidak berada dalam ruang dan waktu; inilah makna keabadian. Padahal, selama kita masih berada di alam semesta, kita belum masuk kepada keabadian. Selama kita hidup di alam semesta kita masih berstatus material yang mengandaikan hidup dalam ruang dan waktu. Ini juga tidak mungkin. Di sini, kita sudah menghadapi persoalan pelik atau kita mau menyebutnya sebagai misteri alam semesta?! Persoalan ini oleh Immanuel Kant disebut sebagai "antinomi ruang dan waktu" (Bdk. Immanuel Kant, Critica della Ragione Pura, hlm. 291-294).
} 
Teorema penciptaan dalam Kitab Kejadian berbicara waktu liturgis. Tradisi para imam memberikan waktu enam hari bertujuan liturgis. Allah bekerja selama 6 hari dan hari ke-7 Allah beristirahat. Maksudnya adalah agar para pendengar Sabda dari Kitab Kejadian memahami bahwa mereka diberikan waktu bekerja selama 6 hari dan pada hari ke-7, mereka diharapkan untuk memuliakan Allah dalam peribadatan. Hari ke-7 dijadikan hari Sabat (istirahat Allah). Mereka tidak boleh melakukan pekerjaan-pekerjaan harian. Mereka hanya diperbolehkan memuliakan Allah dalam acara-acara liturgis. Dengan ini kisah penciptaan bukan hanya bicara soal waktu liturgis tetapi juga maksud kateketis. Dengan bicara waktu 6 hari kerja dan hari ke-7 istirahat, hal ini adalah pengajaran hidup beriman kepada umat beriman.

Teori evolusi alam semesta berbicara waktu kosmologis. Waktu didefinisikan sebagai "jumlah gerakan dalam kaitannya sebelum dan sesudah" (Aristoteles). ${ }^{50}$ Berdasarkan definisi tersebut, waktu kosmologis adalah waktu sebagai perubahan dari momen ke momen dalam kisah alam semesta. Sejauh kita berada di alam, kita berhubungan dengan waktu kosmologis, karena kosmos berarti alam yang teratur. Evolusi kosmos berarti evolusi yang berkaitan dengan alam semesta. Menurut Stephen Hawking, waktu yang dibutuhkan evolusi alam semesta adalah 13,7 milyar tahun. Artinya, alam semesta terjadi sejak peristiwa Big Bang sampai sekarang berlangsung kurang-lebih 13,7 milyar tahun. Apa yang dinyatakan Hawking adalah waktu kosmologis, bukan waktu liturgis. Jika kita melihat perbedaan waktu penciptaan yang butuh 6 hari dan waktu evolusi 13,7 milyar tahun, hal ini bukan untuk dipertentangkan. Alasannya dua konsep waktu berbeda. Waktu kosmologis adalah waktu yang nyata (real time) dan waktu liturgis adalah waktu sebagai simbol (symbolic time). Waktu kosmologis mau bicara waktu yang berlangsung (proses evolusi kosmos), sementara waktu liturgis yang menyimbolkan perihal liturgi (bukan waktu yang nyata).

Selanjutnya, kedua pendekatan berbeda dalam ruang-lingkupnya. Kitab Kejadian adalah buku iman, sementara evolusi kosmos adalah penelitan ilmiah. Karena itu, Kitab Kejadian tidak didasarkan pada

${ }^{50}$ Bdk. Battista Mondin, Epistemologia Cosmologia (Vol.2), hlm. 156. 
penelitian ilmiah tentang proses penciptaan. Kitab Kejadian menyatakan bahwa Allah menciptakan dunia dan segala isinya (Kej 1:1-32) hanya berlangsung 6 hari. Hal ini tidak mau menyatakan waktu berlangsungnya penciptaan (the real time of creation). Kejadian sebagai buku iman mau menyatakan tentang Allah yang menciptakan dunia dengan segala isinya (the real actor of creation). Dengan demikian Kejadian tidak bicara soal proses berlangsungnya penciptaan, tetapi berbicara soal penyebab penciptaan. Kitab Kejadian tidak menjawab, bagaimana berlangsungnya penciptaan (?), tetapi siapa yang melakukan penciptaan (?); Persisnya, siapa pelaku dibalik evolusi kosmos yang begitu mengagumkan ini? Kitab Kejadian menjawab pertanyaan ini; jawabannya adalah Allah sebagai pencipta alam semesta. Dengan kata lain, Kitab Kejadian mau menjawab penyebab alam semesta (causa efficiens). Eksistensi alam semesta disebabkan oleh Allah sebagai Pengada Tak Terbatas yang melampaui ruang dan waktu. Dengan ini, kita dapat mengatakan bahwa Kitab Kejadian mau berbicara perihal "metafisik alam semesta". Di balik semua evolusi alam semesta ada Pengada yang melampaui fisikalitas alam semesta. Allah adalah "Pengada Metafisik" yang menciptakan halhal fisik dari alam semesta.

Jika Kejadian berbicara perihal "metafisik" yaitu "Allah sebagai Pencipta", maka evolusi berbicara perihal "fisik" yaitu "alam semesta sebagai ciptaan". Berkaitan dengan hal fisik, teori evolusi mau menjawab pertanyaan bagaimana alam terbentuk? Teori evolusi kosmos menjawab bahwa alam semesta terbentuk melalui peristiwa Big Bang. Dari peristiwa ini, alam semesta terus berekspansi memperluas dirinya (the expansion of universe). Teori evolusi kosmos juga mau menjawab pertanyaan apa itu alam semesta? Alam semesta berasal dari singularitas yang adalah materi unik dengan kekuatan energi yang luar biasa. Materi ini berkembang menjadi alam semesta. Berdasarkan materi unik sebagai singularitas, alam semesta adalah struktur materi yang berhakikat ruang dan waktu. Dengan ini, kita menyatakan bahwa teori evolusi kosmos membahas causa materialis sekaligus causa formalis. Causa materialis menegaskan bahwa penyebab dari bahan alam semesta adalah materi alam semesta. Sementara, causa formalis menyatakan bahwa penyebab dari bentuk alam semesta adalah wujud alam semesta itu sendiri. 
Keduanya tak dapat dipisahkan: materi mengandaikan forma dan forma mengandaikan materi (hylemorfisme). ${ }^{51}$

\section{Persamaan Keduanya}

Baik Teorema Penciptaan maupun Teori Evolusi kosmos bermula dari ketiadaan. Kalimat pertama dalam Kisah Penciptaan dituliskan dalam bahasa Ibrani, bereshith bara elohim. Hal ini diterjemahkan "Ketika Allah mulai menciptakan". Dengan pernyataan ini, teks Ibrani menyatakan bahwa penciptaan itu berasal dari ketiadaan (creatio ex nihilo). Karena itu, Kisah Penciptaan sebagai creatio ex nihilo, menyatakan tentang awal mulanya ruang dan waktu yang berasal dari ketiadaan (nothingness). ${ }^{52}$ Dalam konteks ilmiah, Karen C. Fox menjelaskan tentang makna ketiadaan (nothingness). Pada awal mula, tidak ada apa pun. Hal ini bukanlah sungguh-sungguh ketiadaan, melainkan ketiadaan yang mempunyai potensi untuk mengada. Sebuah ketiadaan yang mempunyai kandungan energi yang tiba-tiba memancarkan eksistensinya dengan begitu cepat. Ketiadaan ini mempunyai cukup energi untuk lepas-landas yang meledak begitu hebat. Peristiwa ini seperti momen kecil yang sangat tak terbatas. Momen ini selanjutnya menjadi "terang" melintasi waktu dan ruang. Seluruh ruang dan waktu diciptakan dalam momen tersebut. Di dalamnya, energi perlahan-lahan, menjadi materi -proton, neutron, dan poton. Alam semesta yang kecil ini terus berkembang menjadi bintang-bintang dan planet-planet, dan akhirnya bangsa manusia hadir di dalamnya. ${ }^{53}$ Dalam hal ini, Stephen Hawking menyatakan:

Selama beradad-abad, banyak pihak, termasuk Aristoteles, percaya bahwa alam semesta mesti selalu ada untuk menghindari perkara bagaimana alam semesta terbentuk. Yang lain percaya bahwa alam semesta punya awal, dan menggunakan itu sebagai alasan keberadaan Tuhan. Kesadaran bahwa waktu berperilaku seperti

\footnotetext{
51 "Hilemorfisme, menurut substansi material, substansi bagi dirinya, adalah komposisi dari dua prinsip metafisik dan substansial yaitu material prima dan forma substansial" (Lih. Battista Mondin, Epistemologia Cosmologia (Vol.2), hlm. 144).

${ }^{52}$ John A. Moore, From Genesis to Genetics: The Case of Evolution and Creationism, hlm. 28-29.

${ }^{53}$ Lih. Karen C. Fox, The Big Bang Theory, hlm. 9.
} 
ruang menyajikan alternatif baru. Gagasan itu menghilangkan penolakan lama terhadap awal alam semesta, tetapi juga berarti awal alam semesta diatur hukum-hukum sains dan tidak perlu diawali geraknya oleh suatu ilahi. ${ }^{54}$

Meskipun Stephen Hawking menyatakan "alam semesta diatur hukum-hukum sains dan tidak perlu diawali geraknya oleh suatu yang ilahi”, ia tidak pertama-tama menyangkal eksistensi Allah. Dalam pernyataan tersebut, kita dapat mencermatinya. Dari satu pihak, Stephen mau menyatakan bahwa eksistensi hukum-hukum sains mampu menjelaskan eksistensi alam ini. Peran sains memang harus mampu menjelaskan sebab-akibat alam semesta secara positif. Artinya, teorinya tentang penciptaan alam semesta mesti dapat dipertanggungjawabkan secara ilmiah berdasarkah hasil-hasil eksperimen dan observasinya. Dari lain pihak, Stephen tidak menyangkal eksistensi Allah. Sebaliknya, ia mau mengatakan bahwa hukum-hukum sains harus mampu menjelaskan eksistensi alam semesta dalam diri-Nya. Wilayah sains adalah wilayah ilmiah. Sementara, Allah itu wilayah iman. Jika sains adalah wilayah fisik, maka Allah itu wilayah metafisik. Dalam hal ini, Stephen tidak mau mencampuradukan dua wilayah tersebut. Sebaliknya, ia mau konsisten dengan wilayahnya (wilayah sains).

Teori Big Bang cocok dengan Teorema Penciptaan. Stephen Hawking menyatakan bahwa kita hanya tahu apa yang terjadi setelah peristiwa Big Bang. Sebaliknya, kita tidak mengetahui apa pun yang terjadi sebelum Big Bang. Peristiwa sebelum Big Bang tidak dapat menjadi bagian sains untuk alam semesta. Karenanya, kita sebaiknya menyingkirkan peristiwa sebelum Big Bang dari sains. Bagaimanapun, peristiwa sebelum Big Bang belum memasuki ruang dan waktu dan tak bisa dijelaskan karena sains tidak mampu membuat penelitian ilmiah di dalamnya. Kita mesti mengatakan bahwa ruang dan waktu punya permulaan dalam peristiwa Big Bang (Ledakan Besar). Hawking menegaskan bahwa banyak orang tak suka gagasan bahwa waktu punya permulaan, barangkali karena terkesan melibatkan campur tangan Ilahi.

54 Stephen Hawking - Leonard Mlodinov, The Grand Design (Terj. Zia Anshor, Rancang Agung), hlm. 145 
Gereja Katolik menyambut Teori Big Bang dan pada tahun 1951 secara resmi menyatakan bahwa Teori Big Bang cocok dengan Alkitab. ${ }^{55}$

Menurut Kitab Suci, alam semesta berawal dan berakhir; alam semesta diciptakan dan akan musnah pada akhir zaman. Gagasan Kitab Suci ini diperjelas oleh Stephen Hawking. Menurutnya, siklus alam semesta yang berlangsung dari bermilyar-milyar tahun cahaya, terjadi antara sebuah Big Bang sebagai awal dan sebuah Big Crunch sebagai akhir.

Dengan adanya ekspansi alam semesta yang seragam secara ekstrim, hal ini dapat dilukiskan dalam istilah-istilah dari sebuah nomor tunggal, jarak antara dua galaksi. Hal ini masih secara aktual berkembang, tetapi diharapkan bahwa tarikan gravitasi antara dua galaksi berlangsung lambat, kecepatan dari ekspansi alam semesta. Jika kepadatan alam semesta lebih besar pada titik tertentu, tarikan gravitasi akan berhenti pada akhir ekspansi dan akan memaksa alam semesta untuk memberikan awal pada sebuah kontraksi baru. Alam semesta akan hancur pada akhirnya dalam sebuah peristiwa "Big Crunch", sebuah ledakan besar yang akan sangat mirip dengan "Big Bang" yang darinya alam semesta berawal. $^{56}$

Kemusnahan alam semesta dinyatakan baik dalam "Big Crunch" sebagai bagian dari Teori Evolusi atau "Akhir Zaman" sebagai bagian dari Teorema Penciptaan. Berkaitan dengan ini, Teilhard de Chardin sebagai paleontolog memperjelasnya dalam bahasa iman: "Kerajaan Allah ada bersama dengan kita. Ketika Kristus tampak dalam awanawan, Dia segera mewujudkan "metamorfosis alam semesta" yang telah perlahan-lahan disempurnakannya di bawah pengaruhnya dalam jiwa umat manusia. Untuk mempercepat kedatangan-Nya, marilah kita memusatkan diri pada pemahaman yang benar tentang proses, yang melaluinya kehadiran Yang Kudus dilahirkan dan bertumbuh dalam diri

${ }^{55}$ Lih. Stephen Hawking, A Brief History of Time (Terj. Zia Anshor, Sejarah Singkat Waktu), hlm. 68-69.

${ }^{56}$ Lih. Battista Mondin, Epistemologia Cosmologia (Vol.2), hlm. 256-257. 
kita. Untuk mempercepat perkembangannya secara memadai, marilah kita mengamati kelahiran dan pertumbuhan dari kehadiran yang ilahi (the divine milieu), pertama-tama dalam diri kita dan selanjutnya dalam dunia tempat kita berada. ${ }^{57}$

\section{Catatan Akhir}

Rekonsiliasi antara teorema penciptaan dan teori evolusi mempunyai persamaan dan sekaligus perbedaannya. Dalam persamaan, rekonsiliasi keduanya terjadi dengan saling meneguhkan. Teorema penciptaan berpijak pada "metafisika penciptaan" (Allah) dan Teori Evolusi berlandaskan pada "fisika penciptaan" (alam semesta). Keduanya saling meneguhkan bahwa penciptaan berasal dari ketiadaan; Dalam penciptaan, creatio ex nihilo dan singularitas hadir dalam evolusi kosmos. Keduanya saling meneguhkan bahwa alam semesta akan berakhir. Dalam Teori Big Crunch, alam semesta akan berakhir. Persamaan lain adalah alam semesta berlangsung dalam waktu. Bahasa Kejadian menyatakan waktu bersifat simbolis dan bahasa evolusi mengatakan waktu itu kenyataan. Dalam persamaan, rekonsiliasi Teorema Penciptaan dan Teori Evolusi mudah terjadi.

Selanjutnya, rekonsiliasi Teorema Penciptaan dan Teori Evolusi harus terjadi. Di dalam perbedaan, rekonsiliasi terjadi ketika perbedaan dari keduanya saling melengkapi. Teorema Penciptaan menyatakan Allah sebagai "Penyebab alam semesta"; Sementara Teori Evolusi menjelaskan "proses penciptaan" alam semesta. Yang satu berbicara Sang Pencipta, yang lain berbicara penciptaan. Yang satu berbicara causa efficiens dan causa finalis, yang lain berbicara causa materialis dan causa formalis. Artinya, Teorema Penciptaan menekankan Allah sebagai penyebab alam semesta dan sekaligus tujuan dari alam semesta. Sementara Teori Evolusi menekankan proses materi dan perwujudannya menjadi alam semesta. Selanjutnya, Teorema Penciptaan dalam Kejadian adalah pernyataan iman. Dengan kisah penciptaan, orang diajak untuk percaya bahwa Allah adalah Pencipta dari seluruh hal yang mengagumkan di alam semesta ini. Sementara Teori Evolusi adalah pernyataan ilmiah. Teori Evolusi tentang

${ }^{57}$ Lih. Teilhard de Chardin, Le Milieu Divin, hlm. 128. 
alam semesta memberikan pengetahuan tentang proses kelahiran dan perkembangan alam semesta ini. Yang satu bertujuan iman dan yang lain bertujuan pengetahuan. Karena itu, iman tanpa pengetahuan itu bohong, pengetahuan tanpa iman itu sombong.

Berkaitan dengan Teorema Penciptaan dan Teori Evolusi yang saling melengkapi, ada dua hal yang perlu ditegaskan. Dari satu pihak, evolusi kosmos memuncak dalam kehadiran manusia di alam semesta. Hal ini dikatakan bahwa manusia adalah tujuan dari evolusi. Seluruh proses alam yang sedemikian rupa memuncak kepada penciptaan dan kehadiran manusia di tengah-tengah alam semesta ini. Brandon Carter sebagai ahli fisika menyatakan: "Demikianlah terjadi bahwa antara seluruh dunia mungkin terwujud jika tampilnya kehidupan dan karena itu, eksistensi tentang apa pun organisme, yang dapat dilukiskan, menjadi sebagai "penilai dari alam semesta". Dengan ini, Carter menyatakan secara tidak langsung bahwa manusia itu harus ada sebagai tujuan evolusi alam semesta. Lebih tegas lagi, Enrico Zoffoli sebagai filsuf menyatakan: "Dunia tanpa manusia seperti sebuah bangunan yang tidak lengkap dan tidak berguna, 'sebuah tubuh tanpa kepala'; alam semesta akan kehilangan horizon untuk menyatukan bumi dan langit, waktu dan keabadian, yang relatif dan yang absolut. Mediasi yang tak setara dari sebuah pikiran yang berdasarkan pengalaman inderawi, mampu untuk mengabstraksikan pengada dan membuka kepada ketidakterbatasan. Karena itu, gambaran sempurna, harmonis, dan yang dapat memahami dalam keberadaan alam semesta bahwa kebijaksanaan Ilahi mampu menentukan, hanyalah kepada manusia". ${ }^{58}$ Kebenaran ini menegaskan apa yang dikatakan oleh Kitab Kejadian bahwa manusia menjadi tujuan penciptaan sebagai imago Dei (Kej 1:27). Sebagai imago Dei, manusia memiliki akal budi yang mampu memanusiawikan alam semesta dan jiwa rohani yang mampu hidup kekal.

Di lain pihak, evolusi kosmos bergerak kepada "penampakan Ilahi". Teilhard de Chardin sebagai paleontolog menyatakan bahwa ada

58 Battista Mondin menambahkan: "Alam semesta membutuhkan untuk dipertanyakan. Dengan tiadanya pengada bertanya [manusia], alam semesta akan kehilangan penjelasan yang penuh dan jelas untuk memberikan pengetahuan yang benar" (Lih. Battista Mondin, Epistemologia Cosmologia (Vol.2), hlm. 262-264). 
dua titik kritis dari energi manusia yang telah mengambil bentuk yang kita tahu sekarang ini: pertama sebagai "penampakan hidup" yang hadir dalam biosphere (wilayah kehidupan) dan selanjutnya "penampakan akal budi" yang berada dalam noosphere (wilayah pikiran). Metamorfosis ini dapat berlanjut dan mencapai tujuannya pada kehadiran kesadaran pada sebuah "Omega" yang menjadi pusat dari noosphere. Seluruh gerakan evolusi menuju kepada pusat tujuannya yaitu "penampakan Ilahi" dalam teosphere (the appearance of the Theospere). ${ }^{59}$ Dalam teosphere, Allah meresapi seluruh alam semesta dan alam semesta harus dijiwai oleh Allah. Teosphere tidak lain adalah divinisasi alam semesta. Lebih konkret, penampakan Ilahi di dunia ini dinyatakan dalam pewartaan akan Kerajaan Allah oleh Yesus Kristus; Allah harus merajai alam semesta yang mencapai kepenuhan dalam akhir zaman. Menurut Teilhard de Chardin, evolusi alam bergerak dari Titik Alfa kepada Titik Omega. "Singkatnya, kita dapat membandingkan dalam setiap jalan menuju Titik Omega yang dalam Teori Evolusi diramalkan, Kristus menghantar kepada totalisasi spiritual...."60 Dalam Titik Omega itu, "Allah menjadi segala dalam segala". Hal ini ditegaskan oleh St. Paulus: "Tetapi kalau segala sesuatu telah ditaklukkan di bawah Kristus, maka Ia sendiri sebagai Anak akan menaklukkan diri-Nya di bawah Dia yang telah menaklukkan segala sesuatu di bawah-Nya, supaya Allah menjadi semua di dalam semua (1 Kor 15:28).

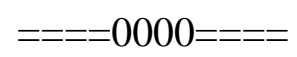

${ }^{59}$ Lih. Teilhard de chardin, Human Energy, hlm. 160.

${ }^{60}$ Lih. Teilhard de chardin, Human Energy, hlm. 155. 


\section{DAFTAR PUSTAKA}

BERTENS, K. Sejarah Filsafat Yunani. Yogyakarta: Kanisius, 1999.

DE Chardin, TeILHARD, Human Energy, London: William Collins Sons \& Co. Ltd, 1969.

--------, Le Milieu Divin, London: Collins Clear - Type Press, 1967.

Embuiru, Herman (Ed.). Katekismus Gereja Katolik. Ende: Percetakan Arnoldus, 1995.

Fox, KAREn C. The Big Bang Theory. New York: John Wiley \& Sons, Inc., 2002.

Hawking, StePhen. The Big Bang and Black Holes. Singapore: World Scientific Publishing, 1993.

---------. A Brief History of Time (Terj. Zia Anshor, Sejarah Singkat Waktu). Jakarta: Gramedia, 2017.

-------- - Leonard Mlodinov, The Grand Design (Terj. Zia Anshor, Rancang Agung). Jakarta: Gramedia, 2017.

Mondin, BAtTista. Epistemologia Cosmologia (Vol.2). Bologna: Edizioni Studio Domenicano, 1999.

Moore, John A. From Genesis to Genetics: The Case of Evolution and Creationism. California: University of California Press, 2002.

PARKER, BARRY. Creation: the Story of the Origine and Evolution of the universe. New York: Plenum Publishing Corporation, 1988.

RANA, FAZALE - Ross, Hugh. Life of Origin. United States America: Rtb Press, 2004.

TOlstikhin, I.N. - KRAmers, J.D. The Evolution of Matter: From the Big Bang to the Present Day. New York: Cambridge University Press, 2008 . 
Tresmontant, Claude. La métaphysique du Christianisme et la naissance de la philosophie chrétienne. Paris: Éditions du seuil, 1959.

Zhi, FAng Li - RufFini, Remo (Ed.). Hawking on the Big Bang and Black Holes. London: World Scientific Publishing, 1993.

SUMBER ONLINE:

https://www.quora.com

https://english.stackexchange.com

ttps://id.wikipedia.org/wiki/Aksioma

https://pendidikan.co.id/aksioma-dan-teorema-pengertian-syarat-dancontoh

https://en.wikipedia.org/wiki/Evolution

https://kbbi.web.id 